\title{
Potensi Limbah Tulang Kambing Sebagai Arang Aktif Yang Teraktivasi Asam Sulfat
}

\author{
Sari Wardani ${ }^{1 *}$, Elvrida Rosa ${ }^{2}$ \\ ${ }^{1,2}$ Staf Pengajar Fakultas Pertanian, Universitas Abulyatama, \\ Jl. Blang Bintang Lama Km 8,5 Lampoh Keudee, Aceh Besar. \\ *Koresponden email: sariwardani_peternakan@abulyatama.ac.id
}

Diterima : 23 Mei 2018

Disetujui : 30 Juli 2018

\begin{abstract}
Bone is one of the wastes result in environmental pollution and public health issues if it is thrown directly into the environment. The aim of this research was to study the characteristics of activated charcoal of activated sulfuric acid goat bone. The process of making activated charcoal of goat bone included two stages of process, herein consisted of first carbonization process of goat bone at temperature of $700{ }^{\circ} \mathrm{C}$ for 20 minutes to produce goat bone charcoal. The second process is chemical activation by using sulfuric acid activator at various concentrations of $1 \mathrm{~N}, 2 \mathrm{~N}$ and $3 \mathrm{~N}$ for 24 hours. The results showed that the best activated charcoal characteristic of sulfuric acid was at $3 \mathrm{~N}$ sulfuric acid concentration, $0.289 \%$ moisture content, ash content of $6.4 \%$, absorption capacity of Iod $983 \mathrm{mg} / \mathrm{g}$, volatile matter 15,017, fixed carbon 82.013 and spectra FTIR of activated carbon showed spectra of absorption band at wave number $3546,143-3604,135 \mathrm{~cm}-1$ on vibration of group -OH, with intensity $76 \%$. Overall, the results revealed that the quality of activated charcoal of goat bone is still eligible of the values recommended by SNI-06-4253-1996 about the quality of activated charcoal.
\end{abstract} Keywords: livestock waste, goat bone, activated charcoal, activator, sulfuric acid,

Abstrak: Tulang merupakan salah satu limbah yang jika dibuang ke lingkungan secara langsung dapat mencemari lingkungan dan dapat berdampak buruk terhadap kesehatan masyarakat. Penelitian ini bertujuan untuk mempelajari karakteristik arang aktif tulang kambing yang teraktivasi asam sulfat. Proses pembuatan arang aktif tulang kambing melalui dua tahapan proses yaitu proses karbonisasi tulang kambing pada suhu $700{ }^{\circ} \mathrm{C}$ selama 20 menit yang akan menghasilkan arang tulang kambing. Proses kedua adalah aktivasi secara kimia dengan menggunakan aktivator asam sulfat pada variasi konsentrasi $1 \mathrm{~N}, 2 \mathrm{~N}$ dan $3 \mathrm{~N}$ selama 24 jam. Hasil penelitian menunjukkan karakteristik arang aktif yang teraktivasi asam sulfat terbaik berada pada konsentrasi asam sulfat $3 \mathrm{~N}$, yaitu kadar air 0,289 $\%$, kadar abu 6,4 \%, daya serap terhadap Iod $983 \mathrm{mg} / \mathrm{g}$, volatile matter 15,017, fixed carbon 82,013 dan hasil spectra FTIR karbon aktif memperlihatkan spectra pita serapan pada bilangan gelombang $3546,143-3604,135 \mathrm{~cm}^{-1}$ pada vibrasi ulur gugus $-\mathrm{OH}$, dengan intensitas $76 \%$. Secara keseluruhan hasil penelitian menunjukkan kualitas arang aktif tulang kambing masih memenuhi SNI-06-42531996 tentang mutu arang aktif.

Kata kunci: limbah peternakan, tulang kambing, arang aktif, aktivator, asam sulfat,

\section{Pendahuluan}

Provinsi Aceh merupakan salah satu provinsi yang jumlah populasi ternak kambing mengalami peningkatan setiap tahunnya. Menurut data Dinas Kesehatan dan Peternakan Provinsi Aceh tahun 2015 jumlah populasi ternak kambing mencapai 112.365 ekor. Peningkatan populasi ternak kambing setiap tahunnya akan meningkatkan limbah yang dihasilkan.

Tulang merupakan salah satu hasil ikutan (by product) dari pemotongan ternak yang sampai saat ini belum termanfaatkan secara maksimal karena sebagian besar masyarakat masih menganggapnya sebagai limbah ternak. Sampai saat ini pemanfaatan 
tulang dari ternak masih sangat terbatas, sehingga dengan demikian tulang masih dikategorikan sebagai by product yang memiliki nilai ekonomi rendah (Said., M.I, 2014)

Tulang kambing merupakan salah satu limbah yang dihasilkan dari ternak kambing. Dari satu ekor kambing dapat menghasilkan 51\% tulang dari total berat ternak atau jika diasumsikan berat satu ekor ternak adalah $40 \mathrm{~kg}$ maka limbah tulang yang dihasilkan sebesar 20,4 kg tulang. Apabila limbah tersebut terus dibuang ke lingkungan tanpa pengolahan terlebih dahulu maka akan sangat berpotensi mencemari lingkungan. Pembuangan limbah ternak sembarangan dapat menyebabkan pencemaran pada tanah, air dan udara, sehingga berdampak terhadap kualitas hidup peternak, ternaknya dan masyarakat umum.

Arang aktif adalah suatu padatan berpori yang mengandung 85-95\% karbon, dihasilkan dari bahan-bahan yang mengandung karbon dengan pemanasan pada suhu tinggi (Chand et al., 2005). Arang aktif banyak diaplikasikan sebagai adsorben pada pemurnian gas, pemurnian pulp, penjernihan minyak, katalis, dan juga untuk pemurnian produk pangan antara lain pembersihan larutan gula tebu, gula bit, gula jagung, menghilangkan rasa dan bau air minum, pemurnian minyak nabati, dan minuman alkohol (Wijayanti, 2009).

Secara kimiawi komposisi penyusunan tulang kambing terdiri dari $\pm 69 \%$ anorganik, $22 \%$ organik dan 9\% air. Fasa organik dari tulang kambing mengandung 90\% kolagen. Fasa organik yang terdapat pada tulang kambing dapat dijadikan sebagai sumber karbon yang dimanfaatkan sebagai bahan baku pembuatan arang aktif tulang kambing (Akbar, 2012). Beberapa penelitian telah membuktikan bahwa arang aktif tulang kambing memiliki kemampuan yang baik untuk menyerap logam berat. Fitryani (2014) menyatakan bahwa arang aktif tulang kambing yang diaplikasikan sebagai adsorben menunjukkan potensi yang cukup besar untuk penyerapan anion seperti sulfat. Sampai saat ini, peneliti belum menemukan jurnal atau penelitian tentang pemanfaatan limbah tulang kambing sebagai arang aktif yang teraktivasi secara kimia. Oleh karena itu, penelitian ini difokuskan pada pemanfaatan limbah tulang kambing yang teraktivasi secara kimia untuk meningkatkan kualitas arang aktif.

Secara fisik tulang memiliki pori-pori yang sangat memungkinkan digunakan sebagai arang aktif karena pori-pori yang terdapat pada tulang kambing mampu mengadsorpsi zat-zat lain ke permukaan pori-pori tulang dan mengandung kalsium hidrosiapatit. Limbah tulang kambing jika tidak ditanggani dengan baik maka akan mencemari lingkungan. Selama ini tulang kambing hanya diolah menjadi tepung tulang sebagai bahan campuran pada pakan ternak, akan tetapi persentasi penambahan tepung tulang pada pakan ternak sangat sedikit, sehingga pemanfaatan limbah tulang kambing sampai saat ini belum maksimal.

Seiring dengan perkembangan ilmu pengetahuan dan teknologi, limbah tulang kambing dapat dimanfaatkan sebagai arang aktif. Penelitian tentang pemanfaatan tulang kambing menjadi arang aktif dengan menggunakan aktivator asam sulfat saat ini belum ditemukan adanya pustaka atau acuan pustaka. Namun demikian, beberapa penelitian tentang pemanfaatan limbah tulang sebagai arang aktif telah dibuktikan secara ilmiah. Seperti yang dikemukakan oleh Previanti, P, dkk. 2015 bahwa arang aktif tulang sapi dapat menyerap logam tembaga sebesar $99,65 \%$ pada kondisi optimum arang aktif pada ukuran partikel 120 mesh, aktivator $5 \%$, waktu kontak aktivasi 24 jam, suhu $800{ }^{\circ} \mathrm{C}$, dan variasi adsorbat dan adsorben 1 gr. Sorbent tulang sapi dapat menyerap ion besi sebesar 99,9624\%, ion tembaga sebesar $99,6484 \%$, ion sulfat sebesar $68,274 \%$ dan ion sianida sebesar $69,594 \%$ dengan

Tabel 1. Hasil uji kualitas arang aktif tulang kambing

\begin{tabular}{llccccc}
\hline \multirow{2}{*}{ No } & $\begin{array}{c}\text { Karakteristik Karbon } \\
\text { Aktif }\end{array}$ & $\begin{array}{c}\text { Arang tulang kambing } \\
\text { sebelum aktivasi }\end{array}$ & $\mathrm{H}_{2} \mathrm{SO}_{4} \mathrm{lN}$ & $\mathrm{H}_{2} \mathrm{SO}_{4} 2$ & $\mathrm{H}_{2} \mathrm{SO}_{4} 3 \mathrm{~N}$ & SNI \\
\hline 1 & Kadar air (\%) & 0.959 & 1,086 & 1,204 & 0,289 & Max 15 \\
2 & Kadar Abu (\%) & 15,411 & 8,333 & 9,060 & 6,397 & Max 10 \\
3 & Volatile Matter (\%) & 14,626 & 18,027 & 16,522 & 15,017 & Max 25 \\
4 & Fixed Carbon (\%) & 82,454 & 78,973 & 80,498 & 81,013 & Min 65 \\
5 & Daya serap Iodium & 920,025 & 900,990 & 970,785 & 983,475 & Min 750 \\
\hline
\end{tabular}


Tabel 2. Bilangan gelombang arang tulang kambing dan arang aktif tulang kambing

\begin{tabular}{|c|c|c|c|c|c|c|c|c|c|c|}
\hline Sampel & \multicolumn{10}{|c|}{ Bilangan Gelombang $\left(\mathrm{cm}^{-1}\right)$} \\
\hline Gusus Fungsi & $\mathrm{O}-\mathrm{H}$ & $\mathrm{C}-\mathrm{H}$ & $\mathrm{C} \equiv \mathrm{C}$ & $\mathrm{C}=\mathrm{C}$ & $\mathrm{C}=0$ & $\mathrm{NO}_{2}$ & $\mathrm{C}-\mathrm{H}$ & $\mathrm{C}-\mathrm{N}$ & $\mathrm{C}-\mathrm{O}$ & $\mathrm{C}-\mathrm{H}$ \\
\hline $\begin{array}{l}\text { Arang tulang } \\
\text { kambing }\end{array}$ & 3205 & $\begin{array}{l}2917 \\
2851\end{array}$ & 2141 & 1637 & - & $\begin{array}{l}1559 \\
1541 \\
1508\end{array}$ & $\begin{array}{l}1457 \\
1411\end{array}$ & 1197 & 1178 & $\begin{array}{l}960 \\
871 \\
717\end{array}$ \\
\hline $\begin{array}{c}\text { Arang Aktif } \\
\text { Tulang } \\
\text { Kambing }\end{array}$ & $\begin{array}{l}3604 \\
3546\end{array}$ & $\begin{array}{l}2920 \\
2852\end{array}$ & $\begin{array}{l}2203 \\
2152\end{array}$ & 1618 & 1706 & 1541 & - & - & $\begin{array}{l}1109 \\
1083\end{array}$ & 720 \\
\hline
\end{tabular}

menggunakan aktivator $\mathrm{Na}_{2} \mathrm{CO}_{3}$ (Syamberah, dkk., 2015). Arang aktif tulang kambing yang diaktivasi dengan $\mathrm{Na}_{2} \mathrm{CO}_{3} 5 \%$ dapat menyerap kation timbal sebesar 99,95\% pada konsentrasi $200 \mathrm{mg} / \mathrm{L}$ (Ulul A, dkk. 2015). Sedangkan dalam beberapa penelitian seperti yang dilakukan oleh Maftuhin (2013) yang menganalisis adsorpsi arang aktif tulang ayam sebagai adsorben ion timbal, dan dalam penelitian tentang adsorbsi ion $\mathrm{Zn}$ dan $\mathrm{Cu}$ dengan menggunakan arang tulang yang dilakukan oleh Wilson et al. (2003), menunjukkan arang tulang beberapa jenis hewan memiliki potensi yang baik untuk mengadsorpsi ion logam.

Aktifator adalah zat atau senyawa kimia yang berfungsi sebagai reagen pengaktif dan akan mengaktifkan atom-atom karbon sehingga daya serapnya menjadi lebih baik. Zat aktifator bersifat mengikat air yang menyebabkan air yang terikat kuat pada pori-pori karbon tidak hilang pada saat karbonisasi, kemudian zat aktifator akan memasuki pori dan membuka permukaan arang yang tertutup. Dengan demikian pada saat dilakukan pemanasan, senyawa pengotor yang berada dalam pori menjadi lebih mudah terserap sehingga luas permukaan karbon aktif semakin besar dan meningkatkan daya serapnya.
Tujuan utama pembuatan arang aktif tulang kambing adalah untuk meminimalkan limbah tulang kambing sehingga dapat mencegah terjadinya pencemaran lingkungan dan sebagai salah satu bentuk pengelolaan limbah hasil peternakan yang berkelanjutan. Pengaruh konsentrasi aktivator asam sulfat dalam pembuatan arang aktif tulang kambing belum banyak diketahui. Oleh karena itu, penelitian ini bertujuan untuk mempelajari kualitas arang aktif tulang kambing yang teraktivasi asam sulfat dengan perlakuan variasi konsentrasi asam sulfat.

\section{Metode Penelitian}

Prosedur penelitian terdiri dari empat tahapan proses yaitu persiapan bahan baku, proses karbonisasi, proses aktivasi dengan asam sulfat dan analisa kualitas arang aktif tulang kambing.

\subsection{Persiapan Bahan Baku}

Sampel yang digunakan dalam penelitian ini adalah limbah tulang kambing yang telah melalui proses perebusan, diambil dari beberapa tempat pembuangan pada rumah potong hewan (RPH) dan rumah makan di sekitaran wilayah Aceh Besar dan Kota Banda Aceh secara acak sederhana (simple random sampling).

Tabel 3. Bilangan Gelombang Arang Tulang Kambing dan Arang Aktif Tulang Kambing

\begin{tabular}{|c|c|c|c|c|c|c|c|c|c|c|}
\hline Sampel & & & & Bilans & in Gelc & bang & $\left.\mathrm{n}^{-1}\right)$ & & & \\
\hline Gusus Fungsi & $\mathrm{O}-\mathrm{H}$ & $\mathrm{C}-\mathrm{H}$ & $\mathrm{C} \equiv \mathrm{C}$ & $\mathrm{C}=\mathrm{C}$ & $\mathrm{C}=0$ & $\mathrm{NO}_{2}$ & $\mathrm{C}-\mathrm{H}$ & $\mathrm{C}-\mathrm{N}$ & $\mathrm{C}-\mathrm{O}$ & $\mathrm{C}-\mathrm{H}$ \\
\hline $\begin{array}{c}\text { Arang tulang } \\
\text { kambing }\end{array}$ & 3205 & $\begin{array}{l}2917 \\
2851\end{array}$ & 2141 & 1637 & - & $\begin{array}{l}1559 \\
1541 \\
1508\end{array}$ & $\begin{array}{l}1457 \\
1411\end{array}$ & 1197 & 1178 & $\begin{array}{l}960 \\
871 \\
717\end{array}$ \\
\hline $\begin{array}{c}\text { Arang Aktif } \\
\text { Tulang } \\
\text { Kambing }\end{array}$ & $\begin{array}{l}3604 \\
3546\end{array}$ & $\begin{array}{l}2920 \\
2852\end{array}$ & $\begin{array}{l}2203 \\
2152\end{array}$ & 1618 & 1706 & 1541 & - & - & $\begin{array}{l}1109 \\
1083\end{array}$ & 720 \\
\hline
\end{tabular}




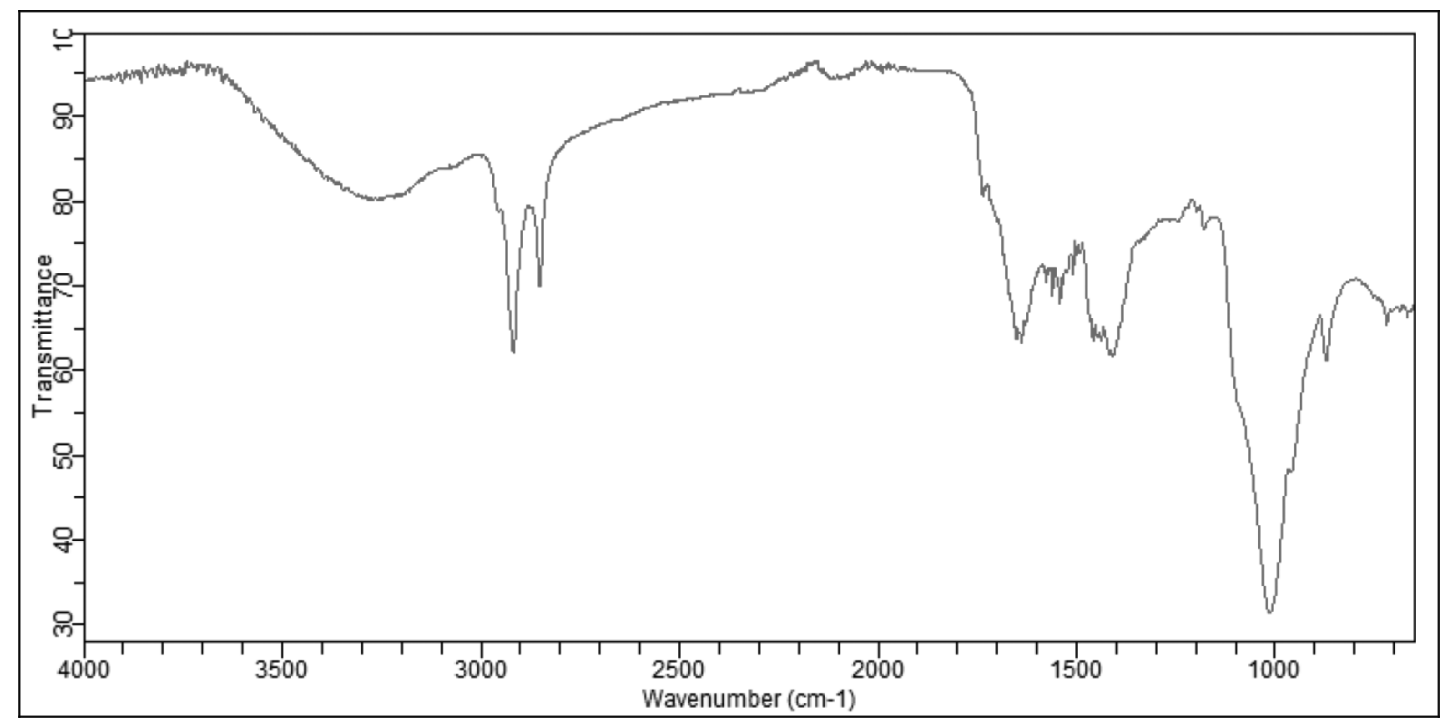

Gambar 1. Difraksi sinar x arang tulang kambing (sebelum aktivasi)

\subsection{Proses Karbonisasi}

Sampel tulang kambing dipisahkan dari sisa daging yang melekat dan dicuci bersih, kemudian dikeringkan. Setelah kering sampel kemudian dipotong hingga ukuran $\pm 3 \mathrm{~cm}$, kemudian dimasukkan ke dalam cawan bertutup, selanjutnya dikarbonisasi di dalam furnace pada suhu $700{ }^{\circ} \mathrm{C}$ selama \pm 20 menit (SNI-06-4253-1996).

\subsection{Proses Aktivasi Secara Kimia}

Arang tulang kambing yang dihasilkan dari proses karbonisasi kemudian dihaluskan dan diayak hingga lolos ukuran 100 mesh. Selanjutnya dilakukan proses aktivasi, yaitu dengan merendam serbuk arang masing-masing sebanyak $10 \mathrm{~g}$ dengan larutan asam sulfat dengan konsentrasi aktivator $1 \mathrm{~N}, 2 \mathrm{~N}$ dan $3 \mathrm{~N}$ masingmasing sebanyak $100 \mathrm{~mL}$ di dalam Beaker gelas $250 \mathrm{~mL}$, diaduk selama 5 menit dan didiamkan 24 jam. Kemudian disaring dan selanjutnya dipanaskan pada suhu $800{ }^{\circ} \mathrm{C}$ selama 15 menit. Arang tersebut kemudian dicuci sampai $\mathrm{pH}$ netral dan dikeringkan dalam oven selama 15 menit, kemudian dimasukkan ke dalam desikator.

\subsection{Analisa Kualitas Arang Aktif Tulang Kambing}

Analisa kualitas arang aktif terdiri dari 3 tahapan uji yaitu:

\subsubsection{Uji karakteristik arang aktif}

Arang yang telah aktif kemudian di analisa karakteristik yang meliputi analisa kadar air,

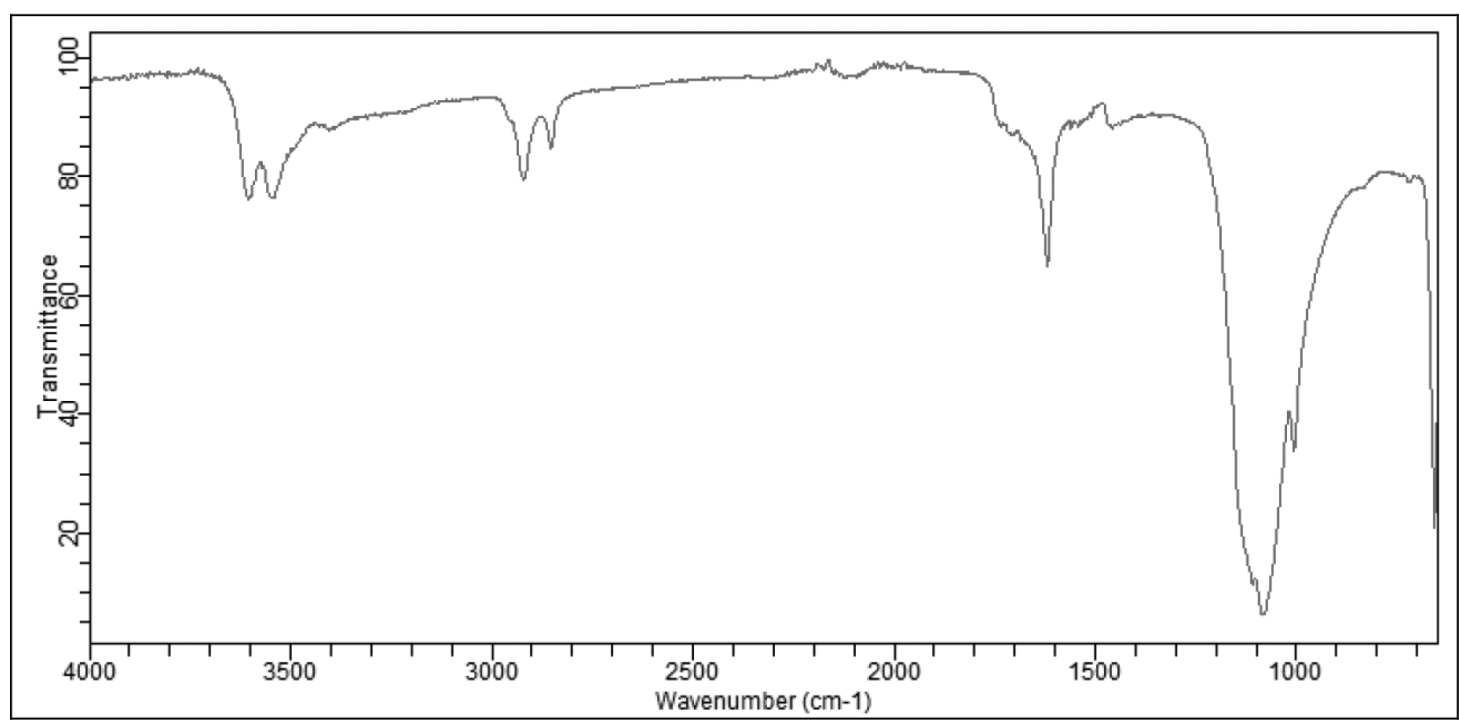

Gambar 2. Difraksi sinar x pada arang aktif tulang kambing (setelah aktivasi) 


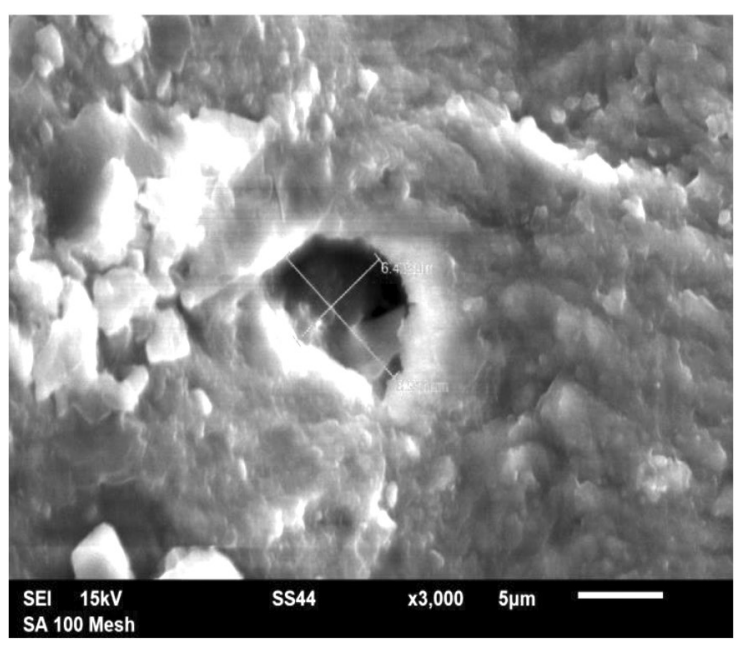

(a)

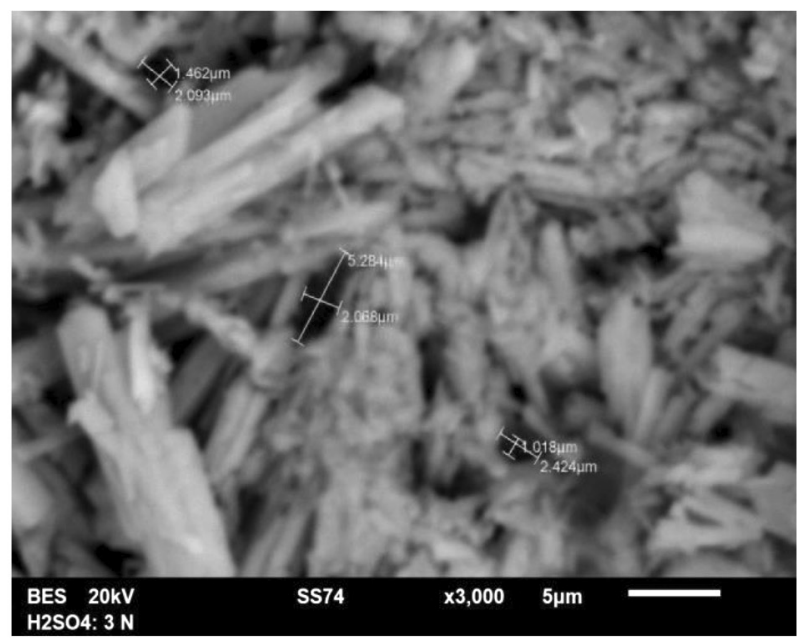

(b)

Gambar 3. (a) Struktur permukaan arang tulang kambing (sebelum aktivasi); (b) arang aktif tulang kambing (setelah aktivasi)

kadar abu, daya serap iodium, volatile matter, fixed carbon. Prosedur analisa karakteristik arang aktif adalah sebagai berikut:

a) Uji Kadar Air (SNI-06-4253-1996)

Timbang 1 gram sampel kedalam kertas saring yang telah diketahui beratnya. Panaskan dalam oven pada suhu $105{ }^{\circ} \mathrm{C}$ selama 3 jam. Dinginkan dalam eksikator dan ditimbang.

Kadar air $(\%)=\frac{W_{1}-W_{2}}{W_{1}} \times 100 \%$

Dimana: $\mathrm{W}_{1}$ adalah bobot sampel sebelum pemanasan (gr) dan $\mathrm{W}_{2}$ adalah bobot air setelah pemanasan (gr)

b) Uji Kadar Abu (SNI-06-4253-1996)

Timbang 1 gram sampel dalam porselin yang telah diketahui beratnya. Diabukan dalam furnace pada suhu $750{ }^{\circ} \mathrm{C}$ selama 1 jam. Kemudian abu didinginkan dalam desikator selama 15 menit lalu ditimbang.

Kadar Abu $=\frac{\text { Berat abu total }}{\text { Berat contoh awal }} \times 100$

c) Uji Volatile Matter (SNI-06-4253-1996)

Timbang porselin, masukkan 1 gram sampel dan timbang kembali. Masukkan porselin yang berisi sampel ke dalam furnace selama 7 menit dengan suhu $900{ }^{\circ} \mathrm{C}$. Keluarkan porselin dari furnace dan ditimbang.

$\mathrm{VM}=\frac{M_{2}-M_{3}}{M_{2}-M_{1}} \times 100-\mathrm{M}$

Dimana: VM (kandungan zat terbang (vollatile matter dalam \%), $\mathrm{M}_{1}$ (berat porselin), $\mathrm{M}_{2}$ (berat porselin dan contoh sebelum dipanaskan),
$\mathrm{M}_{3}$ (berat porselin dan sampel setelah dipanaskan) dan M (kandungan air setelah dianalisa).

d) Uji Fixed Carbon (SNI-06-4253-1996)

Kadar fixed carbon dapat diperoleh dengan rumus:

Fixed Carbon $=100-($ kadar air + kadar abu $+\mathrm{VM})($ dalam \%)

e) Uji Daya Serap terhadap Iodium (SNI-064253-1996)

Arang aktif dipanaskan di dalam oven pada suhu $105^{\circ} \mathrm{C}$ selama $1 \mathrm{jam}$. Arang aktif diambil $0,5 \mathrm{~g}$, lalu ditambahkan $50 \mathrm{~mL}$ larutan iodium 0,1 $\mathrm{N}$ dan diaduk selama 15 menit serta disentrifugal selama 15 menit. Kemudian diambil $10 \mathrm{~mL}$ filtrat dan titrasi dengan menggunakan larutan natrium tiosulfat $0,1 \mathrm{~N}$. Jika warna kuning telah samar lakukan penambahan $1 \mathrm{~mL}$ larutan amilum 1\% sebagai indikator. Proses titrasi diulang kembali hingga warna biru hilang.

Daya serap $\left(\frac{\mathrm{mg}}{\mathrm{g}}\right)=\frac{(\mathrm{V} 1 \mathrm{N1}-\mathrm{V} 2 \mathrm{N2}) \times 12,69 \times 5}{W}$.

Dimana: $V_{1}$ (larutan iodium yang dianalisa, $\mathrm{mL}$ ), $\mathrm{V}_{2}$ (larutan natrium tiosulfat yang diperlukan (mL), $\mathrm{N}_{1}$ (normalitas iodium), $\mathrm{N}_{2}$ (normalitas natrium tiosulfat), $\mathrm{W}$ (berat sampel, gr).

\subsubsection{Uji analisa gugus fungsi arang aktif dengan menggunakan alat Fourier Transform- Infra Red (FT-IR)}

Gugus fungsi arang aktif tulang kambing dianalisa menggunakan alat Fourier TransformInfra Red (FT-IR) dengan spesifikasi alat yang 
digunakan tipe Agilent Technologies Cary 630 FT-IR. Pengujian FT-IR dilakukan pada sampel sebelum dan sesudah aktivasi.

\subsubsection{Uji luas permukaan arang aktif meng- gunakan alat Scanning Electron Microscopy (SEM).}

Analisis strukturpermukaanpori dilakukandengan menggunakan alat Scanning Electron Microscopy (SEM) dengan spesifikasi alat tipe JEOL JSM-6510 LA. Analisis ini bertujuan untuk mengetahui topografi permukaan suatu bahan akibat perubahan konsentrasi aktivator asam sulfat. Pengujian SEM dilakukan pada sampel sebelum dan sesudah aktivasi.

\section{Hasil dan Pembahasan}

\subsection{Identifikasi kualitas arang aktif.}

Kualitas arang aktif diuji atau dinilai berdasarkan Standar Nasional Indonesia (SNI) No. 06-3730-1995 yang meliputi kadar air, kadar abu, volatile matter, fixed karbon, daya serap terhadap iodine. Hasil kadar air. Kadar air berpengaruh besar terhadap kualitas arang aktif. Berdasarkan hasil penelitian kadar air yang diperoleh berkisar antara 0,289-1,204\%. Rendahnya kadar air dapat dikarenakan permukaan arang aktif lebih sedikit mengandung gugus fungsi yang bersifat polar sehingga interaksi antara uap air yang bersifat polar juga sedikit. Secara keseluruhan uji kadar air pada arang aktif tulang kambing telah memenuhi Standar Nasional Indonesia (SNI) 06-3730-95 yaitu sebesar max $15 \%$.

Hasil Analisa Uji Kadar Abu. Kadar abu merupakan sisa dari pembakaran yang sudah tidak memiliki unsur karbon dan nilai kalor lagi. Tujuan penetapan kadar abu adalah untuk mengetahui kandungan oksida logam dalam arang aktif. Nilai kadar abu menunjukkan jumlah sisa dari akhir proses pembakaran berupa zat zat mineral yang tidak hilang selama proses pembakaran. Peningkatan kadar abu terjadi karena terbentuk garam - garam mineral pada saat proses pengarangan yang bila proses tersebut berlanjut akan membentuk partikel - partikel halus dari garam - garam mineral tersebut. Kadar abu dipengaruhi oleh besarnya kadar silika, semakin besar kadar silika maka kadar abu yang dihasilkan semakin besar. Kadar abu arang aktif yang diperoleh berkisar antara 6,397 - 9,060 $\%$. Secara keseluruhan untuk uji kadar abu pada karbon aktif dari arang aktif yang diperoleh telah memenuhi Standar Nasional Indonesia (SNI) 063730-95 yaitu sebesar 10\%.

Hasil Analisa Uji Volatile Matter. Kadar zat mudah menguap merupakan hasil dekomposisi zat-zat penyusun arang akibat proses pemanasan selama pengarangan dan bukan komponen penyusun arang. Arang dengan kadar zat menguap yang tinggi akan menghasilkan asap pembakaran yang tinggi pula pada saat arang tersebut digunakan. Tujuan penetapan kadar zat menguap yaitu untuk mengetahui besarnya kandungan senyawa volatile di dalam arang aktif sebagai hasil dari interaksi antara karbon dengan uap air. Berdasarkan hasil penelitian uji volatile matter untuk arang aktif tulang kambing berkisar antara 15,017 - 18,027\%. Rendahnya kadar zar yang menguap dikarenakan menguapnya senyawa senyawa non karbon yang bersifat volatile pada proses karbonisasi. Secara keseluruhan untuk uji volatile matter pada karbon aktif dari arang aktif yang diperoleh telah memenuhi Standar Nasional Indonesia (SNI) 06-3730-95 yaitu sebesar 25\%.

Hasil Analisa Uji Fixed Carbon. Kadar karbon terikat adalah fraksi karbon yang terikat di dalam arang selain fraksi air, zat menguap dan abu. Tinggi rendahnya kadar karbon terikat di dalam arang di pengaruhi oleh nilai kadar abu, kadar zat mudah menguap dan senyawa hidrokarbon yang masih menempel pada permukaan arang, dan juga dipengaruhi oleh kandungan selulosa dan lignin bahan yang dapat dikonversi menjadi atom karbon. Pada proses adsorpsi penyerapan karbon aktif dipengaruhi oleh banyak tidaknya karbon pada karbon aktif tersebut maka semakin tinggi kadar karbon maka semakin banyak pori - pori yang terbentuk sehingga penyerapan terhadap adsorbat semakin baik. Nilai kadar karbon terikat pada arang aktif tulang pisang berkisar antara 78,973 - 82,013 $\%$. Secara keseluruhan untuk uji fixed carbon pada arang aktif dari tulang kambing yang diperoleh telah memenuhi Standar Nasional Indonesia (SNI) 06-3730-95 yaitu min 65\%.

Hasil Analisa Uji Kemampuan Daya Serap Terhadap Iodin. Parameter yang dapat menunjukkan kualitas arang aktif adalah daya adsorpsi terhadap larutan Iodium. Semakin besar bilangan iodnya maka semakin besar kemampuan dalam mengadsopsi adsorbat. Daya 
serap iodium menunjukkan kemampuan arang aktif menyerap zat dengan ukuran molekul yang lebih kecil dari $10^{\circ} \mathrm{A}$ atau memberikan indikasi jumlah pori yang berdiameter $10-15 \mathrm{~A}$. semakin tinggi daya serap iodium maka semakin baik kualitas arang aktif. Hasil analisa uji kemampuan daya serap iodium pada penelitian ini berkisar antara 901 - 983 mg/g. Secara keseluruhan untuk uji daya serap iodine pada arang aktif dari tulang kambing yang diperoleh telah memenuhi Standar Nasional Indonesia (SNI) 06-3730-95 yaitu min $750 \mathrm{mg} / \mathrm{g}$. Hasil analisa kualitas arang aktif tulang kambing secara keseluruhan disajikan pada Tabel 1.Perbandingan hasil penelitian terhadap beberapa penelitian terdahulu tentang karakteristik arang aktif dari limbah tulang disajikan pada Tabel 2.

\subsection{Identifikasi Gugus Fungsi.}

Gugus fungsi arang aktif tulang kambing dianalisa menggunakan alat Fourier TransformInfra Red (FT-IR) dengan spesifikasi alat yang digunakan tipe Agilent Technologies Cary 630 FTIR. Perubahan gugus fungsi arang aktif sebelum di aktivasi dan setelah aktivasi $\mathrm{H}_{2} \mathrm{SO}_{4} 3 \mathrm{~N}$ disebabkan oleh pengaruh perubahan konsentrasi aktivator asam sulfat. Hasil analisis FT-IR dapat dilihat pada Gambar 1 dan Gambar 2 serta pada Tabel 2.

Spektrum FTIR arang aktif tulang kambing mempunyai pita serapan pada bilangan gelombang sebelum aktivasi pada $3205 \mathrm{~cm}^{-1}$ yang merupakan gugus fungsi $\mathrm{OH}$. Serapan pada $2917 \mathrm{~cm}^{-1}$ dan 2851 $\mathrm{cm}^{-1}$ menunjukkan adanya vibrasi $\mathrm{C}-\mathrm{H}$ alifatik. Pita serapan pada $2141 \mathrm{~cm}^{-1}$ menunjukkan adanya vibrasi regangan gugus $\mathrm{C} \equiv \mathrm{C}$. Kemudian terdapat serapan pada $1637 \mathrm{~cm}^{-1}$ yang merupakan gugus $\mathrm{C}=\mathrm{C}$. serapan pada $1559 \mathrm{~cm}^{-1}, 1541 \mathrm{~cm}^{-1}$ dan 1508 $\mathrm{cm}^{-1}$ menunjukkan adanya vibrasi pada gugus fungsi $\mathrm{NO}_{2}$. Pita serapan pada $1457 \mathrm{~cm}^{-1}$ merupakan gugus fungsi $\mathrm{C}-\mathrm{H}$ dalam bentuk alkana dan diperkuat pita serapan $960 \mathrm{~cm}^{-1}, 871 \mathrm{~cm}^{-1}$ dan $717 \mathrm{~cm}^{-1}$ yang merupakan gugus fungsi C-H dalam bentuk alkena. Selanjutnya terdapat pita serapan pada $1197 \mathrm{~cm}^{-1}$ yang merupakan gugus fungsi $\mathrm{C}-\mathrm{N}$ dan diperkuat pita serapan $1178 \mathrm{~cm}^{-1}$ yang merupakan gugus C-O.

Sementara itu hasil analisis FT-IR pada arang tulang kambing yang terlah diaktivasi pada asam sulfat $3 \mathrm{~N}$ dapat dilihat terjadi perubahan pola spectrum serapat infra-red (IR) dari arang tulang kambing menjadi arang aktif tulang kambing yaitu terjadi pergeseran bilangan gelombang dari $3205 \mathrm{~cm}^{-1}$ ke $3546 \mathrm{~cm}^{-1}$ dan terbentuknya serapanbaru pada bilangan gelombang 3604 $\mathrm{cm}^{-1}$. Pergeseran juga terjadi pada pita serapan $2917 \mathrm{~cm}^{-1} \mathrm{ke} 2920 \mathrm{~cm}^{-1}, 2851 \mathrm{~cm}^{-1}$ ke $2852 \mathrm{~cm}^{-}$ 1, $2141 \mathrm{~cm}^{-1} \mathrm{ke} 2152 \mathrm{~cm}^{-1}$ dan terbentuk pita serapan baru pada panjang gelombang 2203 $\mathrm{cm}^{-1}$. Pergeseran pita serapan juga terjadi pada gugus fungsi $\mathrm{C}=\mathrm{C}$ dari $1637 \mathrm{~cm}^{-1} \mathrm{ke} 1681 \mathrm{~cm}^{-1}$. Sedangkan pada gugus fungsi $\mathrm{NO}_{2}$ tidak terjadi perubahan pita serapan pada $1541 \mathrm{~cm}^{-1}$ tetapi terjadi penghilangan dua pita serapan yaitu pada pita serapan $1559 \mathrm{~cm}^{-1}$ dan $1508 \mathrm{~cm}^{-1}$. Pergeseran pita serapan juga dialami pada gugus fungsi $\mathrm{C}-\mathrm{O}$ dari $1178 \mathrm{~cm}^{-1} \mathrm{ke} 1109 \mathrm{~cm}^{-1}$ dan membentuk pita serapan baru pada $1083 \mathrm{~cm}^{-1}$. Pada gugus fungsi C-H terjadi perubahan pita serapan pada $717 \mathrm{~cm}^{-1}$ ke $720 \mathrm{~cm}^{-1}$ dan juga terjadi penghilangan dua pita serapan yaitu pada $960 \mathrm{~cm}^{-1}$ dan $871 \mathrm{~cm}^{-1}$. Arang aktif tulang kambing yang telah diaktivasi dengan asam sulfat $3 \mathrm{~N}$ mengalami penambahan pita serapan baru yaitu pada panjang gelombang $1706 \mathrm{~cm}^{-1}$ yang merupakan gugus fungsi $\mathrm{C}=\mathrm{O}$. Arang aktif tulang kambing setelah aktivasi juga terjadi penghilangan gugus fungsi yaitu pada gugus fungsi $\mathrm{C}-\mathrm{N}$ jika dibandingkan dengan arang tulang kambing sebelum diaktivasi.

Arang aktif tulang kambing yang dihasilkan memiliki pola serapan dengan jenis ikatan $\mathrm{OH}$, $\mathrm{C}-\mathrm{H}, \mathrm{C}-\mathrm{O}, \mathrm{C} \equiv \mathrm{C}, \mathrm{C}=\mathrm{C}$ dan $\mathrm{NO}_{2}$. Adanya ikatan $\mathrm{OH}$ dan $\mathrm{C}-\mathrm{O}$ menunjukkan bahwa arang aktif tulang kambing yang di hasilkan cenderung bersifat lebih polar. Dengan demikian arang aktif yang dihasilkan dapat digunakan sebagai adsorben zat yang cenderung polar seperti untuk penjernihan air, gula, alcohol atau sebagai penyerap formaldehid.

\subsection{Identifikasi pori arang aktif tulang kambing.}

Analisis struktur permukaan pori dilakukan dengan menggunakan alat Scanning Electron Microscopy (SEM) dengan spesifikasi alat tipe JEOL JSM-6510 LA. Analisis ini bertujuan untuk mengetahui topografi permukaan suatu bahan akibat perubahan konsentrasi aktivator asam sulfat. Hasil analisis SEM dapat dilihat Gambar 3.

Hasil analisis SEM menunjukkan bahwa arang tulang kambing yang belum diaktivasi belum banyak menunjukkan adanya pori. Selain itu penggunakan 
asam sulfat pada konsentrasi $3 \mathrm{~N}$ telah membuka pori-pori menjadi lebih besar dan membuka poripori berukuran kecil. Hal ini menunjukkan bahwa asam sulfat dapat mengurangi senyawa hidrokarbon yang masih menmpel pada permukaan arang.

Terbentuknya pori disebabkan adanya penguapan zat terbang dari bahan baku akibat proses karbonisasi. Karbonisasi telah menyebabkan komponen bahan terdegradasi menghasilkan produk gas $\left(\mathrm{CO}, \mathrm{CO}_{2}\right.$, hydrogen dan metan), produk cair (tar, hidrokarbon, cuka kayu dan air) dan produk padatan yaitu arang. Secara keseluruhan arang dan arang aktif tulang kmabing termasuk ke dalam struktur makropori karena mempunyai diameter berkisar antara $1,018 \mu$ sampai 5,284 $\mu$.

\section{Kesimpulan}

Peningkatan konsentrasi aktivator asam sulfat akan meningkatkan kualitas arang aktif tulang kambing sehingga pori yang terbentuk bertambah besar. Konsentrasi aktivator asam sulfat berpengaruh terhadap tekstur pori yang terbentuk dimana sebelum aktivasi pori yang terbentuk sangat sedikit tetapi setelah diaktivasi maka pori yang terbentuk lebih besar dan banyak. Arang aktif tulang kambing yang dihasilkan memiliki pola serapan dengan jenis ikatan $\mathrm{OH}, \mathrm{C}-\mathrm{H}, \mathrm{C}-\mathrm{O}, \mathrm{C} \equiv \mathrm{C}, \mathrm{C}=\mathrm{C}$ dan $\mathrm{NO} 2$. Adanya ikatan $\mathrm{OH}$ dan $\mathrm{C}-\mathrm{O}$ menunjukkan bahwa arang aktif tulang kambing yang di hasilkan cenderung bersifat lebih polar. Meskipun masih terdapat ikatan $\mathrm{C} \equiv \mathrm{C}$ dan $\mathrm{C}=\mathrm{C}$ yang bersifat non polar. Perlu dilakukan kajian pemanfaatan arang aktif tulang kambing sebagai bahan penjernih air atau penyerap polutan.

\section{Ucapan Terima Kasih}

Penulis mengucapkan terima kasih kepada Direktorat Riset dan Pengabdian Masyarakat (DRPM), Kementerian Riset, Teknologi dan Pendidikan Tinggi yang telah memberikan bantuan dana Hibah Penelitian Dosen Pemula (PDP) dengan no kontrak 05/HIBAH-DIKTI/ LPPM/III/2018, selanjutnya ucapan terima kasih kepada Universitas Abulyatama Aceh Besar yang telah memberikan dukungan dan fasilitas sehingga tercapainya target penelitian ini.

\section{Daftar Pustaka}

Akbar, M. 2012. Pengaruh Waktu Kontak Terhadap Daya Adsorpsi Tulang Sapi Pada
Ion Timbal $(\mathrm{Pb} 2+)$. Jurnal Riset. Universitas Negeri Makassar, Makassar.

Chand, Bansal, Roop, Meenakshi Goyal. 2005. Activated Carbon Adsorpsion. United States of America (USA): Lewis Publisher

Dinas Kesehatan Hewan dan Peternakan Aceh, 2015. Status Populasi Ternak Provinsi Aceh Tahun 2015. Provinsi Aceh

Fitryani, R. 2014. Potensi Abu Tulang Kambing Sebagai Adsorben Ion Sulfat. in: Skripsi FMIPA Kimia, Universitas Riau.

Maftuhin. 2013. Potensi Tulang Ayam sebagai Adsorben Logam Timbal. in: Skripsi FMIPA Kimia, Universitas Riau.

Previanti, P., Sugiani, H., Pratomo, U dan Sukrido., 2015, Daya Serap Dan Karakteristik Arang Aktif Tulang Sapi Yang Teraktivasi Natrium Karbonat Terhadap Logam Tembaga. Jurnal Chimica et Natura Acta Vol. 3 No. 2, Hal 48-53.

Said, M, I, 2014, Pemanfaatan Limbah Tulang, Universitas Hasanuddin.

SNI. 1996, Arang Aktif Untuk Air Minum, Standar Nasional Indonesia, No. 06-42531996, Departemen Perindustrian RI: hal 29 - 57. Jakarta

Syamberah, Anita, S., dan Hanafifah, T. A., 2015, Potensi Arang Aktif Tulang Sapi Sebagai Adsorben Ion Besi, Tembaga, Sulfat dan Sianida Dalam Larutan. Jurnal JOM FMIPA Vol. 2 No.1 pp. 38-47. Universitas Riau.

Siregar, I.D.K., Heryanto, R., Riyadhi, A., Lestari, H.T dan Nurlela, 2015. Karakteristik Karbon Aktif Asal Tumbuhan dan Tulang Hewan Menggunakan FTIR dan Analisis Kemometrika. Jurnal Kimia Valensi: Jurnal Penelitian dan Pengembangan Ilmu Kimia, Vol 1. No 2. Hal 103-116.

Ulul, A., Hanafifah, A dan Anita, S., 2015, Potensi Arang AktifTulang Kambing Sebagai Adsorben Ion Tembaga, Timbal, Nitrat dan Sianida Dalam larutan. JOM FMIPA Vol. 2 No. 1

Wilson, J., Pulford, I., and Thomas, S. 2003. Sorption of $\mathrm{Cu}$ and $\mathrm{Zn}$ by bone charcoal. Environmental geochemistry and health, 25(1): 51-56

Wijayanti R. 2009. Arang Aktif Dari Ampas Tebu Sebagai Adsorben Pada Pemurnian Minyak Goreng Bekas. Tesis Program Pasca Sarjana, Bidang Ilmu Kimia, Institut Pertanian Bogor 